\section{Anaphylactic Reaction to Chlorpropamide}

\author{
M. RAVID, E. RUBINSTEIN, S. CABILI
}

British Medical fournal, 1971, 3, 162

The total incidence of untoward reactions to chlorpropamide is about 6\% (Sayers and Travis, 1965). Gastrointestinal symptoms, skin reactions, and blood dyscrasias constitute the major groups (Stein et al., 1964; Dinsdale et al., 1968; Aecker and Hynes, 1969; Norman et al., 1970). The anaphylactic reaction to chlorpropamide as described in the following case has, to the best of our knowledge, not been hitherto reported.

\section{Case History}

A 46-year-old sanitation worker was admitted to hospital after sudden onset of nausea, retrosternal pressure, and confusion. Diabetes mellitus had been found two months earlier and treated for three weeks by $500 \mathrm{mg}$ of chlorpropamide daily. The patient then stopped the medication. No history of untoward reaction to the drug could be elicited in retrospect. Polydipsia and polyuria made him seek medical help and he was again given chlorpropamide. On the morning of admission he ingested his first two chlorpropamide tablets and then had breakfast; a few minutes later he complained of nausea and increasing retrosternal pressure. He became confused and collapsed and was rushed to hospital.

Examination showed pallor, cyanosis, tachypnoea, and tachycardia; the systolic blood pressure was $30-40 \mathrm{~mm} \mathrm{Hg}$. Blood was drawn for glucose determination, and $\mathbf{4 0} \mathrm{ml}$ of $50 \%$ glucose solution was injected intravenously. When his condition failed to improve $400 \mathrm{mg}$ of hydrocortisone followed by $1,500 \mathrm{ml}$ of isotonic

Tel-Hashomer Hospital and Tel-Aviv University Medical School, Israel

M. RAVID, M.D., Assistant Physician and Instructor in Medicine

E. RUBINŚTEIN, M.D., Resident Physician

S. CABILI, M.D., Assistant Physician and Instructor in Medicine saline and $46 \mathrm{mEq}$ of sodium bicarbonate were rapidly administered intravenously. Blood pressure then rose to $140 / 80$, he regained consciousness, and the cyanosis subsided. The E.C.G. was normal. The initial blood glucose level (drawn before the intravenous injection of glucose) was $278 \mathrm{mg} / 100 \mathrm{ml}$. The hyperglycaemia was subsequently controlled on tolbutamide and he was discharged.

Two weeks later he was readmitted because of urticaria. Treatment with tripelennamine and prednisolone for four days brought no relief. Tolbutamide was then withdrawn and the hyperglycaemia was controlled on 24 units of NPH (isophane) insulin. Less than 24 hours after the withdrawal of tolbutamide the urticaria disappeared. The presence of reaginic antibodies to chlorpropamide was tested by means of the Prausnitz-Küstner reaction: $0.2 \mathrm{ml}$ of the patient's serum was injected intracutaneously into the forearms of three physicians. Twenty-four hours later a similar volume of chlorpropamide solution in isotonic saline (containing about 5 $\mathrm{mg}$ of chlorpropamide) was injected into the prepared site and into the contralateral forearm. A typical weal and flare reaction 40 by $20 \mathrm{~mm}$ in diameter appeared within 5 to 15 minutes at the prepared sites in all three volunteers, while no reaction occurred at the control sites.

\section{Comment}

The Prausnitz-Küstner reaction is a time-honoured, reliable procedure for the demonstration of reaginic antibodies. The positive test for anaphylaxis, together with the clinical signs of vascular collapse about half an hour after ingestion of 500 $\mathrm{mg}$ of chlorpropamide and in the presence of high blood glucose, leave little doubt about the anaphylactic aetiology of this patient's vascular shock. The urticaria, which was probably due to tolbutamide, may suggest the existence of crosssensitivity between chlorpropamide and tolbutamide.

\section{References}

Aecker, R. R., and Hynes, H. E. (1969). Archives of Internal Medicine, 123, 445.

Dinsdale, R. C. W., Ormerod, T. P., and Walker, A. E. (1968). British Medical fournal, 1, 100.

Norman, P. S., Levine, M., and Smith, M. (1970). Drugs of Choice. 19701971, ed. M. Modell, pp. 36, 472. Saint Louis, Mosby.

Sayers, G., and Travis, R. H. (1965). In The Pharmacological Basis of Therapeutics, ed. L. S. Goodman and A. Gilman, 3rd edn., p. 1596. New York. Macmillan.

Stein, J. H., Hamilton, H. E., and Steets, R. F. (1964). Archives of Internal 